\title{
Pendampingan Pastoral Pasangan Pernikahan yang Mengalami Krisis Relasi Dengan Dasar Kejadian 2:24
}

\section{Pastoral Assistance for Married Couples Experiencing Relationship Crisis Based on Genesis 2:24}

\author{
Fenti Yusana ${ }^{1)^{*}}$ \\ 1) Sekolah Tinggi Theologia Intim Makassar \\ *Penulis Korespondensi: fentiylaban01@gmail.com
}

Received: 06/15/2020/ Accepted: 28/12/2021/ Published: 29/12/2021

\begin{abstract}
Abstrak
Tujuan penulisan artikel ini adalah untuk mendapatkan perspektif pernikahan Kristen menurut standar Firman Allah, prinsip utama pernikahan Kristen sehingga artikel ini dapat menjadi jalan yang benar untuk membangun kembali hubungan yang sudah rusak dalam pernikahan Kristen. Panggilan membaharui komitmen dalam pernikahan Kristen adalah panggilan iman untuk memuliakan Tuhan yang memberkati pernikahan Kristen. Teks yang sengaja penulis pilih adalah Kejadian 2:24. Penulis memilihnya dikarenakan di dalamnya terdapat beberapa prinsip pernikahan yang dapat diambil. Metode yang penulis pergunakan adalah metode studi kasus. Hasil penelitian adalah perlu diadakan pastoral pra dan pasca nikah. Kedua pastoral tersebut dilakukan untuk mengingatkan suami dan istri akan prinsip penting dalam Kejadian 2:24. Pertama, melalui pastoral pra dan pasca nikah, suami dan istri mengerti dan diingatkan selalu akan pernikahan yang dikehendaki Allah adalah pernikahan monogami. Kedua, melalui pastoral pra dan pasca nikah, suami dan istri mengerti dan diingatkan bahwa mereka adalah dua pribadi yang telah menjadi satu daging (dwitunggal). Ketiga, melalui pastoral pra dan pasca nikah, suami dan istri dikuatkan untuk menjalani pernikahan sebagai persekutuan hidup.
\end{abstract}

Kata-kata Kunci: Kejadian 2:24, Krisis Relasi, Pasangan, Pastoral, Pendampingan, Pernikahan Kristen.

\begin{abstract}
The purpose of writing this article is to get a perspective of Christian marriage according to the standards of God's Word, the main principle of Christian marriage so that this article can be the right way to rebuild the broken relationship in Christian marriage. The call to renew commitments in Christian marriages is a call of faith to glorify God who blesses Christian marriages. The text that the author deliberately chose is Genesis 2:24. The author chose it because in it there are several principles of marriage that can be taken. The method that the author uses is a case study method. The result of the research is that pre- and post-wedding pastoral care is necessary. Both pastorals
\end{abstract}


are done to remind husbands and wives of an important principle in Genesis 2:24. First, through pre- and post-wedding pastoral care, husband and wife understand and are reminded that the marriage that God wants is a monogamous marriage. Second, through pre- and post-wedding pastoral care, husband and wife understand and are reminded that they are two persons who have become one flesh (dwitunggal). Third, through pre- and post-wedding pastoral care, husband and wife are strengthened to live marriage as a community of life.

Keywords: Christian Marriage, Genesis 2:24, Mentoring, Pastoral, Relationship Crisis, Spouse.

\section{PENDAHULUAN}

Pernikahan yang ideal, harmonis, serasi dan rukun sejahtera adalah dambaan semua orang tanpa terkecuali juga dalam kehidupan keluarga Kristen, orang Kristen ataupun kelompok masyarakat kristiani di mana pun berada. Untuk itu diadakanlah berbagai seminar, persekutuan doa, penerbitan buku buku kristiani yang fokus membahas soal pernikahan yang bahagia, strategi memelihara pernikahan, merawat pernikahan dan lain sebagainya. Bagaimana hasilnya? Tentu banyak yang berhasil dalam merawat pernikahannya, berbahagia dengan pasangannya, berbangga dan bersukacita dalam pernikahan, tetapi tidak dapat dipungkiri banyak juga pasangan Kristen yang mengalami kegoncangan dalam pernikahan karena disebabkan oleh berbagai hal yang tidak mampu diatasi dengan mendasarkan dan merujukkannya pada rencana Agung Tuhan Allah dalam pernikahan Kristen.

Krisis relasi yang muncul di dalam keluarga dan rumah tangga Kristen yang muncul beberapa di antara dapat dilihat dalam contoh berikut. Pertama, pasangan suami isteri yang selalu terlihat sebagai pasangan ideal, harmonis, rukun, sama cerdas, pelayan di dalam jemaat, memiliki pekerjaan yang membanggakan dan berduit banyak, dengan anugerah fisik: suami berwajah tampan, dan isteri berwajah cantik berkulit putih, tiba-tiba mengumumkan bahwa hubungan mereka sudah diambang perceraian karena hadirnya pria idaman lain. Kedua, pasangan muda, mereka sudah menjalani masa pacaran selama lima tahun sebelum memutuskan untuk menikah, alumni jebolan universitas bergengsi di ibu kota, berasal dari kalangan bourjouis, mengadakan pesta pernikan ditempat yang mewah dengan undangan yang banyak dan jamuan menu yang mewah, setelah menjalani masa pernikahan, kebahagiaan yang dirasakan hanya seumur jagung karena salah satu pasangan menjadi "dingin" sehingga pasangannya merasakan terabaikan, dan kondisi ini terus memengaruhi komitmen dalam melaksanakan tanggung jawab kepemimpinan dalam hal tanggung jawab bekerja dan memelihara keluarga, 
sehingga memunculkan pertanyaan "siapa yang bertanggung jawab di sini?" Akhirnya mereka memutuskan untuk sepakat pisah tempat tinggal.

Ketiga, sebut saja dua sejoli sedang kasmaran berencana untuk menikah dan membangun kehidupan bersama sebagai suami-isteri namun rencana tersebut tidak dapat dilanjutkan karena adanya pengaruh dan dominasi yang negatif dari orang tua karena level, status dan kepemilikan yang tidak seimbangan. Ini juga masalah yang dipaparkan oleh Dlaifurrahman (2018, p. 31). Yang terjadi kemudian terjadi perang dingin antara anak orangtua, keluarga dengan keluarga bahkan menimbulkan kebencian terhadap pihak pihak lainnya yang dianggap terlibat dalam pembatalan pernikahan tersebut. Keempat, rentannya relasi pernikahan sah karena hadirnya mantan yang belum bisa dilupakan, akibatnya merusak nilai-nilai kekudusan dalam pernikahan: suami isteri berpisah tempat tinggal, lalu isterinya membangun hubungan yang baru dengan mantannya, tinggal bersama tanpa ikatan dengan melibatkan seluruh anggota keluarga pacarnya dan anaknya yang masih kecil. Selain itu ada juga permasalahan yang diakibatkan oleh ketegangan-ketengangan antara suami dan istri (Birditt dkk., 2017, p. 1995). Selain perselingkuhan dan faktor orang tua, ada faktor-faktor lain seperti penggunaan uang yang ceroboh, kebiasaan minum alkohol atau narkoba dan kebiasaan-kebiasaan yang dianggap menjengkelkan (Amato dan Rogers, 1997, p. 612).

Gambaran-gambaran di atas menunjukkan telah terjadi krisis relasi yang mengakibatkan penurunan nilai-nilai pernikahan Kristen yang sakral, kudus, dan murni, sebagaimana tujuan Allah menciptakan pernikahan pada awal mulanya, terjadi penyimpangan yang tidak sesuai dengan standar Firman Allah, terjadi dekadensi moral dan penghancuran nilai-nilai kebenaran dalam pernikahan Kristen.

Dalam kondisi yang sedemikian parah, siapakah yang bertanggung jawab? Pertanyaan yang selalu tidak mudah dijawab karena melibatkan banyak pihak dan sulitnya untuk membicarakan dan memahami persoalan ini. Karena itu kita perlu kembali ketujuan awal dari dibentuknya relasi pernikahan Kristen dengan mengajukan beberapa pertanyaan penting, yaitu:

1. Mengapa pernikahan Kristen harus dibangun menurut standar Firman Allah? Mengapa Pernikahan Kristen harus berbeda dengan pernikahan lainnya? Mengapa nilai kekudusan, kasih, pengampunan perlu menjadi prinsip utama dalam pernikahan Kristen?

2. Bagaimana membangun hubungan yang sudah rusak dalam pernikahan Kristen? Bagaimana mengembalikan kasih yang mula-mula di antara pasangan suami isteri sehingga tidak menempuh jalan perpisahan dan perceraian? Bagaimana membarui komitmen dalam pernikahan Kristen?

3. Siapa yang utama dalam sebuah relasi pernikahan: pasangan atau orang tua dan keluarga?

Semua pertanyaan yang muncul harus diletakkan kembali kepada Firman Allah dan apa yang sesungguhnya yang menjadi rencana agung Tuhan Allah atas pernikahan Kristen dan atas orang orang Kristen yang menghidupi pernikahannya. 
Berdasarkan latar belakang di atas itulah, sehingga penulis tertarik untuk menulis artikel ini. Tujuan penulisan artikel ini adalah untuk dapat memahami dan membangun secara benar perspektif pernikahan Kristen menurut standar Firman Allah; memahami keutamaan pernikahan Kristen yang berbeda dengan pernikahan lainnya yang di dalamnya ada nilai kekudusan, kasih, pengampunan menjadi prinsip utama dalam pernikahan Kristen. Tulisan ini juga diharapkan dapat menjadi jalan yang benar untuk membangun kembali hubungan yang sudah rusak dalam pernikahan Kristen. Betapa pentingnya untuk mengembalikan kasih yang mula-mula di antara pasangan suami isteri sehingga tidak menempuh jalan perpisahan dan perceraian. Dengannya panggilan membarui komitmen dalam pernikahan Kristen adalah panggilan iman untuk memuliakan Tuhan yang memberkati pernikahan Kristen. Siapa yang utama dalam sebuah relasi pernikahan: pasangan atau orang tua dan keluarga bukan lagi menjadi soal yang dapat menghancurkan relasi untuk membangun pernikahan Kristen.

\section{METODE}

Metode yang penulis pergunakan dalam artikel ini adalah metode analisis studi kasus yang adalah bagian dari penelitian kualitatif (Prihatsanti, Suryanto dan Hendriani, 2018, p. 126). Menurut Merriam dan Tisdell, studi kasus berkaitan dengan fenomena suatu kejadian. Penelitian dilakukan dengan meneliti pertanyaan dan masalah penelitian fenomena tersebut (Yin, 2002, p. 16; Prihatsanti, Suryanto dan Hendriani, 2018, p. 128).

\section{HASIL DAN PEMBAHASAN}

\section{Pernikahan Kristen Menurut Alkitab}

\section{Pernikahan dalam Perspektif Kejadian 2:18-25}

Sejak awal Penciptaan Allah, pernikahan adalah satu bagian yang merupakan rancangan Tuhan yang paling istimewa dan terencana. Begitu istimewa dan terencananya sehingga Tuhan Allah mengaturnya sedemikian rupa dari ide dan inisiatif-Nya yang tak terselami oleh ciptaan-Nya sampai kapanpun. Pernikahan adalah lembaga pertama yang ditetapkan dan dikehendaki oleh Tuhan Allah sendiri atas manusia (Subeno, 2008, p. 2). Pernikahan dalam pandangan Tuhan Allah sejak awal mulanya sudah dapat kita temukan dalam kitab Kejadian 2:18-25.

Dari teks Kejadian 2:18-25 kita dapat melihat tujuan Allah menciptakan lembaga pernikahan bagi manusia. Pertama, pernikahan adalah lembaga yang memberikan ruang dan tempat bagi manusia dewasa, seorang laki-laki dewasa dan seorang perempuan dewasa untuk mencari, memilih dan memiliki "penolong baginya, yang sepadan dengan dia". Kedua, pernikahan adalah tempat di mana manusia diberi kuasa untuk "memberi nama". Memberi nama di sini bermakna khusus sehingga 
antar "si penolong yang sepadan" dan "yang ditolong dalam kesepadanan" memiliki kuasa untuk memberi nama pada relasi dan hubungan mereka yang khusus itu dengan nama "ikatan kudus dalam pernikahan". Demikian seterusnya kuasa itu memberikan spirit cinta kasih yang merangkul di antara mereka. Ketiga, pernikahan adalah cara Allah yang sempurna untuk menjawab pencarian nan sepi yang ada dalam diri manusia dengan memberikan apa yang berasal dari dirinya sendiri. Dari materi yang sama, Tuhan "membangun seorang perempuan, lalu dibawa-Nya kepada manusia itu." Walaupun materinya sama dengan manusia (laki-laki), tetapi di tangan Tuhan, Tuhan membangun perempuan itu sedemikian berbeda dengan manusia itu. Ketika perempuan itu dibangun-Nya, perempuan itu sungguh nan istimewa dan sungguh nan menarik rupa sehinga tidak ada samanya dengan makhluk manapun yang telah diberi nama oleh manusia itu atas "segala ternak, segala binatang di hutan dan segala burung diudara dan semua makhluk hidup lainnya." Pada fase ini, manusia mulai menyadari kesendiriannya dan merasakan adanya kebutuhan akan orang lain. Orang lain dalam hal ini bukan beberapa orang secara berkelompok namun SATU orang tertentu yang sangat khusus baginya (Agustinus, 2004, p. 1). Keempat, pernikahan adalah tempat diwujudkannya anugerah TUHAN untuk komitmen bersepakat antara manusia dengan Tuhan, bahwa benar "Inilah dia, tulang dari tulangku dan daging dari dagingku. la akan dinamai perempuan, sebab ia diambil dari laki-laki." Manusia itu harus bersepakat dengan anugerah rencana Tuhan, harus berkoneksi dengan pikiran Tuhan tentang pasangannya, harus menerima hadirnya perempuan itu sebagai bagian dari dirinya yang secara kuat membentuk sikap menerima, mengakui, merespons dan setuju dalam rasa saling menghormati dengan perempuan itu. Bukankah Raja Salomo dalam Amsalnya pernah berkata: "Siapa mendapat isteri, mendapat sesuatu yang baik, dan ia dikenan TUHAN ... isteri yang berakal budi adalah karunia TUHAN." (Amsal 18:22; 19:14). Kelima, pernikahan merupakan tempat untuk membuktikan adanya kesiapan kedewasaan di dalam roh dan karakter Kristus untuk saling bertangung jawab, melengkapi dan menyempurnakan kehidupan antara laki laki dan perempuan sebagai "belahan jiwanya" lalu mengikatkan diri dalam suatu kesatuan pernikahan untuk menjalani kehidupan ini bersama-sama. Kesatuan yang dibentuk tidak hanya dalam kesatuan biologis saja, melainkan juga dalam kesatuan spiritual. Kesatuan spiritual ini diwujudkan dalam kesadaran pemeliharaan relasi, kehidupan dan kesejahteraan lahir batin. Kesatuan ini membentuk ikatan kudus, baik ikatan lahiriah maupun ikatan batiniah karena di antara mereka ada Tuhan yang selalu hadir untuk menolong dan menjauhkan dari dosa penyelewengan atas kekudusan pernikahan.

\section{Pernikahan dalam Perspektif Teks Kejadian 2:24 sebagai Dasar Pendampingan Pastoral Pasangan Pernikahan yang Mengalami Krisis Relasi}

Prinsip dasar pernikahan Kristen semakin jelas tergambar dalam kitab Kejadian 2:24 ini. "Sebab itu seorang laki-laki akan meninggalkan ayahnya dan ibunya dan bersatu dengan isterinya, sehingga keduanya menjadi satu daging." Ada penekanan 
utama dari prinsip pernikahan Kristen yang dapat kita temukan disini. Pertama, Pernikahan Kristen bersifat monogami. Pernikahan monogami adalah pernikahan yang ditetapkan oleh Tuhan Allah (Verkuyl, 1993, p. 59). Pernikahan yang berlangsung antara satu pria dengan satu wanita. Mengapa? Sebab sejak awalnya, rencana Tuhan Allah dengan pernikahan adalah bahwa Allah tidak memberikan banyak Adam kepada satu Hawa, atau banyak Hawa kepada satu Adam (Subeno, 2008, p. 16). Tidak mungkin kasih pernikahan dibagi kepada banyak orang. Setiap pernikahan yang melanggar prinsip ini tidak akan pernah menikmati secara sempurna keindahan pernikahan, tetapi sebaliknya, akan menjadi akar dari berbagai masalah yang timbul (Subeno, 2008, p. 16). Dengan pernikahan monogami ini menjadikan prokreasi, komplementasi, keindahan kesatuan di dalam keperbedaan, yang tidak pernah tercapai jika keduanya satu jenis mewujudkan maksud pernikahan agung daripada Tuhan Allah sendiri. Pernikahan monogami perlu ditegakkan secara sepenuh hati mengingat dalam konteks Perjanjian Lama tampak bahwa maraknya gejala poligami atau permaduan memasuki juga lingkungan orang orang beriman (Verkuyl, 1993, p. 59). Ada anggapan bahwa di dalam Perjanjian Lama permaduan itu tidak terlarang, tetapi diterima dengan tiada yang menentangnya (Verkuyl, 1993, p. 59), padahal ini keliru dan salah. Sesungguhnya permaduan dalam Perjanjian Lama dipandang sebagai bentuk pernikahan yang merusak maksud Tuhan dengan nikah itu.

Dalam Kitab Kejadian, gejala permaduan itu mulai timbul di lingkungan keturunan Kain. Keturunan Kain tidak mau tunduk kepada Hukum ataupun Injil Tuhan. Lamekh, menolak monogami dan memilih poligami, memilih permaduan (Verkuyl, 1993, p. 59). Jelas dalam Kejadian 4:17-24, Lamekh itu bagaikan sedang menarikan tarian perang bersama sama dengan kedua isterinya, yaitu Ada dan Zila. Dalam nyanyian perang itu tampak tiga motif, yaitu: dendam, keangkuhan dan eros, cinta berahi (Verkuyl, 1993, p. 59). Pernikahan permaduan ini juga terjadi pada lingkunga orang orang beriman, misalnya dalam pernikahan Abraham, Jakub, Daud, Salomo dan yang lainnya. Pernikahan permaduan adalah bentuk dosa terhadap Tuhan (1 Tim. 3:2).

Kedua, Pernikahan Kristen bersifat Dwitunggal. Ungkapan tegas dalam Alkitab mengatakan:" seorang laki laki akan meninggalkan ayahnya dan ibunya dan bersatu dengan isterinya, sehingga keduanya menjadi satu daging." Kebenaran Alkitab ini harus menjadi pengetahuan dan kesadaran bagi pasangan yang hendak menikah, mereka harus secara masak-masak memikirkan rencana pernikahan itu agar mereka betul-betul bisa menjalankan prinsip Alkitab ini. Pernikahan dwitunggal adalah menjadikannya dua orang menjadi satu daging, tidak boleh ada tempat bagi hadirnya orang ketiga/pihak ketiga, selain Allah yang adalah Pencipta dan Penetap lembaga pernikahan. Persatuan tubuh bukan sekedar untuk memperoleh keturunan, melainkan secara mendalam dan khusus sebagai pernyataan kasih sayang secara badani antara suami isteri. Dalam persetubuhan itu suami isteri boleh merasakan rahasia dwitunggal yang dibukakan oleh Tuhan didalam pernikahan (Verkuyl, 1993, p. 77). Rahasia 
persetubuhan hanya boleh dialami bersama-sama dengan dia, yang kepadanya si suami telah mengikat dirinya untuk seumur hidup, demikian sebaliknya bagi si isteri.

Ketiga, Pernikahan bersifat sebagai persekutuan hidup. Ketika laki laki bersatu dengan isteri menjadi satu tubuh dan menginggalkan ayahnya dan ibunya, sesungguhnya itu tidak berarti bahwa laki laki itu melupakan dan mengabaikan orangtua dan keluarganya. Maksud Tuhan dengan pernikahan ini adalah supaya pernikahan ini menjadi suatu persekutuan hidup antara suami isteri secara khusus yang dengannya turut menyatukan kedua belah pihak keluarga besarnya. Persekutuan hidup ini meliputi seluruh kehidupan, suatu persekutuan yang sejati yang menyatukan keluarga. Meninggalkan ayahnya dan ibunya tidak bermaksud melupakan dan mengabaikan orang tuanya. Justru ini menjadi kesempatan bagi seorang laki laki/suami untuk bertanggung jawab dihadapan orangtua dan keluarga bahwa ia mampu bertanggung jawab mengatur dan memimpin keluarga dan rumahtangganya bersama isterinya. Keputusan untuk menikah, menjadikan suami dan isteri saling mengutamakan seorang dengan yang lain sehingga tidak memberikan kesempatan kepada pihak ketiga untuk melakukan "politik devide et impera", yaitu upaya memecah belah keluarga (Subeno, 2008, p. 19).

\section{Kasus-kasus}

\section{Kasus Pertama}

Pasangan suami isteri yang selalu terlihat sebagai pasangan ideal, harmonis, rukun, sama cerdas, pelayan didalam jemaat, memiliki pekerjaan yang membanggakan dan berduit banyak, dengan anugerah fisik: suami berwajah tampan, dan isteri berwajah cantik berkulit putih, tiba-tiba memproklamirkan bahwa hubungan mereka sudah diambang perceraian karena hadirnya orang ketika dengan munculnya pria idaman lain.

Analisis Kasus Pertama: Setelah melakukan pendampingan pastoral terhadap pasangan ini beberapa hal yang dapat ditarik sebagai analisis atas kasus pertama. Data yang ditemukan:

$\checkmark$ Masalah telah muncul dari awal pernikahan yang tidak didasari rasa cinta kasih, melainkan rasa kasihan dari pihak perempuan karena adanya permintaan dari orangtua laki laki untuk menyelamatkan anaknya yang mempunyai hubungan terlarang dengan perempuan yang tidak seiman.

$\checkmark$ Karena jenjang pendidikan dan pekerjaan kedua hampir sama level-nya, sehingga keduanya berusaha untuk saling menyesuaikan. Faktor ekonomi dan prestise turut memengaruhi secara kuat.

$\checkmark$ Pelayanan dijadikan alat untuk ajang kesalehan rohani, tidak jarang menjadi ajang persaingan diantara suami isteri, siapa yang lebih layak melayani.

$\checkmark$ Nilai kekudusan pernikahan yang rusak karena kehadiran pihak ketika, ketidaksetiaan terhadap pasangan.

$\checkmark \quad$ Kecanggihan IPTEK dan Media Sosial digunakan secara negatif 


\section{Kasus Kedua}

Pasangan muda, mereka sudah menjalani masa pacaran selama lima tahun sebelum memutuskan untuk menikah, alumni jebolan universitas bergengsi di ibu kota, berasal dari kalangan bourjouis, mengadakan pesta pernikan ditempat yang mewah dengan undangan yang banyak dan jamuan menu yang mewah, setelah menjalani masa pernikahan, kebahagiaan yang dirasakan hanya seumur jagung karena salah satu pasangan menjadi "dingin" sehingan pasangannya merasakan terabaikan, dan kondisi ini terus mempengaruhi komitmen dalam melaksanakan tanggung jawab kepemimpinan dalam hal tanggung jawab bekerja dan memelihara keluarga, sehingga memunculkan pertanyaan "siapa yang bertanggung jawab disini?", akhirnya mereka memutuskan untuk sepakat pisah tempat tinggal.

Analisis Kasus Kedua: Setelah melakukan percakapan dan pendampingan pastoral terhadap pasangan ini beberapa hal yang dapat ditarik sebagai analisis atas kasus pertama. Data yang ditemukan:

$\checkmark \quad$ Usia pacaran tidak menjamin pengenalan terhadap pasangan dalam pernikahan

$\checkmark$ Menikah karena mengikuti permintaan orang tua karena sudah mengenal dan seiman

$\checkmark$ Terkejut dan kaget terhadap realitas motivasi berumahtangga dari pasangan.

$\checkmark$ Ketika sudah berumahtangga, komunikasi antara suami isteri tidak terbuka.

$\checkmark$ Hubungan dan keintiman menjadi dingin.

$\checkmark$ Pasangan/suami yang tidak mempunyai daya juang dalam bekerja karena secara ekonomi isteri lebih mapan dan sukses dalam bekerja/berbisnis.

$\checkmark$ Pasangan yang pasif dan tidak ada upaya untuk memperbaiki keadaan dan bertanggung jawab terhadap keluarga.

\section{Kasus Ketiga}

Dua sejoli sedang kasmaran berencana untuk menikah dan membangun kehidupan bersama sebagai suami-isteri namun rencana tersebut tidak dapat dilanjutkan karena adanya pengaruh dan dominasi yang negative dari orangtua karena level, status dan kepemilikan yang tidak seimbangan. Yang terjadi kemudian terjadi perang dingin antara anak orang tua, keluarga dengan keluarga bahkan menimbulkan kebencian terhadap pihak pihak lainnya yang dianggap terlibat dalam pembatalan pernikahan tersebut.

Analisis Kasus Ketiga: Setelah melakukan pendampingan pastoral terhadap pasangan ini beberapa hal yang dapat ditarik sebagai analisis atas kasus pertama. Data yang ditemukan

$\checkmark$ Masalah tingkat ekonomi yang tidak sama.

$\checkmark$ Masalah harta warisan yang sudah dibicarakan oleh kedua sejoli, membuat orangtua laki laki tersinggung dan merasa dilewati/tidak dianggap.

$\checkmark$ Ketakutan orang tua terhadap kematian anaknya jika ia tetap menikah dengan pacarnya karena adanya pengaruh ilmu hitam. 
$\checkmark$ Kedua orang tua dari belah pihak saling membenci, menolak dan menggeraskan hati.

$\checkmark$ Restu orang tua tidak dimiliki.

$\checkmark$ Kedua pemuda hidup dalam kebencian, kemarahan, kecurigaan.

\section{Kasus Keempat}

Rentannya relasi pernikahan sah karena hadirnya mantan yang belum bisa dilupakan, akibatnya merusak nilai-nilai kekudusan dalam pernikahan: suami isteri berpisah tempat tinggal, lalu isterinya membangun hubungan yang baru dengan mantannya, tinggal bersama tanpa ikatan dengan melibatkan seluruh anggota keluarga pacarnya dan anaknya yang masih kecil.

\section{Analisis Kasus Keempat.}

$\checkmark$ Keduanya terikat dengan hubungan masalah lalu yang sulit dan tidak mau dilepaskan.

$\checkmark$ Rumahtangga sang pacarnya menjadi rusak dan hancur, berpisah dengan suaminya.

$\checkmark$ Mereka menjalani kebersamaan secara terbuka dan tinggal bersama tanpa ikatan. Ronda mengatakan, "manusia sekarang memasuki era monogamy simultan (simultaneous monogamy), yaitu menjalani kehidupan monogamy, tetapi dengan berganti ganti pasangan atau kawin cerai. Anehnya, banyak orang yang baik merasa oke saja melakukan itu (Ronda, 2015, p. 110).

$\checkmark$ Anak dilibatkan secara sepihak untuk menerima perilaku orangtua

$\checkmark$ Keluarga besar tidak punya hak suara untuk menegur karena ketergantungan ekonomi dan demi alasan kemapanan.

\section{Rencana Aksi: Tahap Pendampingan Pastoral}

Dari keempat kasus dan analisis yang ditampilkan sudah sangat jelas betapa krusialnya masalah-masalah yang muncul di sekitar pernikahan Kristen. Pernikahan Kristen sedang terancam oleh musibah besar jika kita tidak kembali kepada asal mula rencana Tuhan Allah atas kehidupan manusia melalui lembaga pernikahan. Orang Kristen harus menyadari bahaya besar ini dan harus kembali dengan segera kepada kebenaran Firman Tuhan dalam Alkitab.

\section{Pastoral Pra-Nikah}

Menikah tanpa persiapan pra-nikah seperti memulai bisnis atau usaha penting tanpa mempersiapkan yang matang. Jika menikah tanpa persiapan pra-nikah sebelumnya, realitasnya setengah dari semua pernikahan berakhir dengan perceraian dan hanya setengah dari mereka yang bertahan dan benar benar senang dalam jangka panjang (Pangaribuan, 2015, p. 77). Persiapan pra-pernikahan didasarkan pada kenyataan bahwa itu penting untuk memperkuat hubungan dan jalan untuk mempersiapan dalam menghadapi tantangan di masa depan dalam perjalanan 
berumahtangga. Di sini, konseling pastoral pra-nikah menjadi suatu pendidikan atau menjadi suatu pencegahan.

Tujuan dari konseling pastoral pra-nikah ini menuju kepada pembangunan dan menjaga pertumbuhan sikap seseorang untuk menikah berdasarkan prinsip Firman Allah dalam Akitab. Hubungan pra-nikah yang sehat lebih mendalam dari sekeder jalan-jalan dan makan-makan bersama, melainkan lebih pada adanya kepastian hubungan yang telah nyata mereka telah berada pada level persiapan pernikahan. Itu berarti jika berada di level ini, segala prioritas dan agenda hubungan yang dimiliki tentunya makin menjadi berbeda, terencana dan makin terarah.

Apa yang diperlukan dalam proses ini? Beberapa hal yang penting untuk diperhatihan dalam pra nikah, diantaranya:

$\checkmark$ Kesiapan mental yang makin matang dan dewasa untuk memasuki jenjang hubungan yang tinggi lagi. Dua sejoli bukan lagi seorang bujang/lajang yang masih dapat bertingkah laku dan berbuat sekehendak hatinya ketika saat masih awal berpacaran, melainkan kedua sejoli harus secara sadar dan bertanggung jawab atas keputusan memasuki masa pra-nikah atas pasangannya. Kesiapan mental ini akan menolong mereka untuk menghadapi realitas pernikahan yang akan dimasuki bersama. Bukan tidak mungkin ada kesalahpahaman, ada keterkejutan atas keberadaan pasangan dan keluarga serta ikatan budayanya, atau hal lain yang dapat menimbulkan luka batin.

$\checkmark$ Dalam proses ini juga diperlukan untuk menyesuaikan nilai-nilai kehidupan. Oleh karena itu, pasangan pra-nikah harus banyak menghabiskan waktu komunikasi yang betul-betul mengkomunikasikan nilai-nilai hidup yang mereka miliki atas berbagai aspek kehidupan (Agustinus, 2004, p. 93). Mengapa ini penting? Karena sesungguhnya, sepasang sejoli ini dibesarkan dan dibentuk dalam nilai-nilai hidup berkeluarga yang berbeda. Jika ini tidak dilakukan besar kemungkinan, dikemudian hari fondasi hidup pernikahan mereka menjadi sangat rapuh, jika sejak awalnya mereka tidak berkomunikasi secara terbuka dan tidak mau mengubah nilai-nilai hidup yang lama dan membangunnya berdasarkan nilainilai hidup yang baru yang berdasarkan kebenaran Firman Tuhan.

$\checkmark \quad$ Hal lain yang juga penting untuk dipersiapkan dalam masa pra-nikah, mau tidak mau, suka tidak suka, siap-tidak siap, kedua sejoli harus mulai membuat kesepakatan perencanaan anggaran keuangan, dan bagian ini sangat tepat dengan prinsip-prinsip iman dimana masa ini keduanya sedang membawa rencana pra-nikah ini ke dalam hikmat Tuhan segingga kelak mereka dimampukan untuk mengatur aliran keuangan dalam keluarganya kelas. Ini sangat penting membicarakan dan memperjelasnya diawal pra-nikah. Bagaimana jika ada utang yang dibawa masing masing atau salah satu dari mereka? Ini juga harus dibicarakan dalam proses pastoral pra-nikah ini. Mesti jelas alasan dan tujuan dari utang tersebut? Bagaimana penyelesaian selanjutnya? Siapa yang bertanggung jawab menyelesaikannya? Karena itu, betapa pentingnya untuk 
membuat perencanaan anggaran keuangan secara realitis dan membuat prioritas kepentingan yang matang.

$\checkmark$ Menentukan tempat tinggal selanjutnya setelah menikah. Umumnya, isteri mengikuti suaminya setelah menikah, ada baiknya tapi itu jangan dijadikan patokan. Jadikan destiny ilahi sebagai penentu atas setiap keputusan besar yang akan kita ambil dalam berkeluarga (Agustinus, 2004, p. 97). Tujuan pernikahan bukan hanya bersatunya kita dengan orang yang kita cintai, melainkan kita menikah karena kita menyadari adanya keterbatasan yang kita miliki secara pribadi dalam menyelesaikan, mewujudkan kehendak Tuhan dalam kehidupan kita: sematamata untuk mewujudkan kepentingan Kerajaan Sorga. Dengan demikian, tempat tinggal kita harus diselaraskan dengan rencana yang Tuhan tetapkan dalam pernikahan kita. Jelas, setiap pasangan memiliki destiny mereka sendiri di dalam Tuhan.

$\checkmark$ Rencana memiliki anak atau tidak menjadi penting untuk dibicarakan mengingat bahwa keberadaan anak atai ketidakberadaan anak seringkali dijadikan alasan untuk keluar dari destiny Tuhan atas pernikahan? Kalau diberikan Tuhan anak, maunya berapa? Laki laki perempuan sama saja bukan? Kalau tidak beroleh anak, bolehkah mengadopsi anak? Akan mengadopsi anak dari keluarga siapa suami? Isteri? Atau orang atau suku lain? Anak kandung adau anak adopsi sumbernya tentu dari Tuhan Allah yang memberikannya kepada pasangan suami isteri, namun soal membuat dan merencanakannya itu soal pasangan nikah.

$\checkmark$ Milikilah pekerjaan atau usaha pasti sebelum menikah. Menikah berarti siap bertanggung jawab, pria kepada isteri dan sebaliknya.

$\checkmark$ Jangan terlibat dalam seks pra-nikah yang dapat menimbulkan luka dan kepahitan hidup dikemudian hari. Milikilah hidup pernikahan yang dapat kita jadikan warisan teladan bagi anak cucu di kemudian hari dan bagi komunitas.

\section{Pastoral Pasca Nikah: 4, 8, 12 Tahun}

Yang sering dilupakan oleh gereja dan persekutuan adalah pentingnya memberikan pastoral konseling kepada pasangan nikah dan keluarga dalam usia pernikahan berjalan. Setelah pemberkatan nikah dan pencatatan sipil pernikahan, maka urusan dan perjalanan keluarga Kristen menjadi urusannya masing-masing pasangan. Justru di sinilah harus ditopang, dikuatkan, ditolong untuk menjalani dan melintasi tahun tahun pernikahan dari setiap pasangan. Pada usia pernikahan berapa tahunkah pastoral itu dilaksanakan? Pertimbangkan usia pernikahan pada usia pernikahan 4, 8 dan 12 tahun. Jangka waktu 4 tahun dipandang baik untuk melakukan pendampingan pastoral.

Setelah menikah, pasangan suami isteri harus mengalami kepuasan hidup yang sejati bersama pasangan yang Tuhan telah berikan kepadanya. Pasangan kita seharusnya menjadi orang yang terdekat dengan kita dalam hubungan dengan anggota keluarga lainnya. Tidak boleh ada hubungan yang lebih dekat dari pada hubungan yang kita miliki dengan pasangan kita. Bahkan dalam hubungan dengan 
anak sekalipun, anak tidak boleh menjadi lebih dekat kepada kita dibandingkan pasangan kita sendiri. Jangan sampai kita mengorbankan suami atau isteri demi anak. Sebagai pasangan suami isteri, kita harus sehati, sepikir dan sejalan untuk menanggulanggi anak, sehingga dengan demikian kita dapat menjadi teladan dalam kebenaran dan contoh yang baik bagi pernikahan mereka di kemudian hari.

Pasangan yang sehat adalah pasangan yang saling mendukung, mendorong dan membangun. Pasangan saling menolong untuk merayakan pernikahan di dalam Kristus. Pasangan yang menikah menyaksikan kedalaman kasih Kristus. Sumpah mereka berfokus dan membatasi mereka untuk hanya mengasihi satu orang secara ekslusif, permanen, dan intim (Scazzero, 2016, p. 94).

Setiap orang Kristen memiliki panggilan utama yang sama: Kita dipanggil kepada Yesus, oleh Yesus, dan bagi Yesus. Panggilan pertama kita adalah mengasihi Dia dengan seluruh keberadaan kita dan mengasihi sesame kita seperti diri kita sendiri. Para penulis Alkitab telah mengunakan banyak analogi untuk mengambarkan relasi kita dengan Allah (gembala/domba, tuan/budak, orangtua/anak), tetapi mungkin yang paling komprehensif dan cocok adalah pernikahan (Yeh. 16; Mrk. 2:1920; Why. 19-22; Scazzero, 2016, p. 92).

\section{Kesimpulan}

Rencana aksi pendampingan - baik pastoral pra maupun pasca nikah kembali membawa istri dan suami kepada prinsip pernikahan dalam Kejadian 2:24. Pertama, melalui pastoral pra dan pasca nikah, suami dan istri mengerti dan diingatkan selalu akan pernikahan yang dikehendaki Allah adalah pernikahan monogami. Sejak mulanya Allah telah menetapkan pernikahan adalah satu pria dan satu wanita. Kedua, melalui pastoral pra dan pasca nikah, suami dan istri mengerti dan diingatkan bahwa mereka adalah dua pribadi yang telah menjadi satu daging (dwitunggal). Perselingkuhan adalah kesalahan dan dosa yang besar. Hal ini mencemari ikatan hubungan 1 daging suami dan istri. Terakhir, melalui pastoral pra dan pasca nikah, suami dan istri dikuatkan untuk menjalani persekutuan hidup. Ini melibatkan keluarga masing-masing pihak juga. Perseteruan antara suami istri berkaitan dengan keluarga harus segera diselesaikan. Kehendak Allah, tidak hanya hubungan suami istri, namun hubungan antara kedua belah pihak keluarga juga erat dan kuat.

\section{Merayakan Keajaiban Pernikahan Bersama Kasih Kristus}

Tahun tahun kebersamaan dalam pernikahan adalah tahun tahun pernikahan Kristen yang menyaksikan sesuatu yang lebih penting dari dirinya- yaitu Kristus. Pernikahan seperti ini adalah sebuah tanda dan keajaiban. Ketika Kristus mengubah air menjadi anggur, dikatakan itulah mujizat pertama-Nya. Mujizat itu menyaksikan Yesus yang adalah Mesias sebagai anggur terbaik yang akan muncul ketika sejarah dunia sudah berakhir. Mujizat itu menyaksikan bahwa Yesus adalah anggur yang tidak pernah habis, selalu memuaskan dan tidak pernah sampai terbuang. Kasih 
dalam pernikahan menyatakan bagaimana Allah mengasihi dunia- secara total, setia, bebas, dan berbuah (Scazzero, 2016, p. 106).

Serupa dengan apa yang digambarkan Paulus di Efesus 5:25-27, Yesus mengasihi pengantin perempuan-Nya, jemaat, sepenuhnya, sehingga la menyerahkan diri-Nya untuknya, "untuk menguduskannya, sesudah la menyucikannya dengan memandikannya dengan air dan firman, supaya dengan demikian la menempatkan jemaat di hadapan diri_nya dengan cemerlang tanpa cacat atau kerut atau yang serupa itu, tetapi supaya jemaat kudus dan tidak bercela" (Brake, 2018, p. 337).

\section{KESIMPULAN}

Dari beberapa kasus yang penulis paparkan, perlu diadakan pastoral pra dan pasca nikah. Pastoral pasca nikah dilakukan dengan jarak 4 tahun (4, 8, dan 12 tahun masa pernikahan). Kesimpulannya, kedua pastoral dilakukan untuk mengingatkan suami dan istri akan prinsip penting dalam Kejadin 2:24. Pertama, melalui pastoral pra dan pasca nikah, suami dan istri mengerti dan diingatkan selalu akan pernikahan yang dikehendaki Allah adalah pernikahan monogami. Kedua, melalui pastoral pra dan pasca nikah, suami dan istri mengerti dan diingatkan bahwa mereka adalah dua pribadi yang telah menjadi satu daging (dwitunggal). Ketiga, melalui pastoral pra dan pasca nikah, suami dan istri dikuatkan untuk menjalani pernikahan sebagai persekutuan hidup.

\section{KEPUSTAKAAN}

Agustinus, Steven. (2004). Pasangan Prophetik. Jakarta: Nafiri Gabrier.

Amato, P. R., \& Rogers, S. J. (1997). A Longitudinal Study of Marital Problems and Subsequent Divorce. Journal of Marriage and Family, 59(3), 612-624. https://doi.org/10.2307/353949.

Birditt, K. S., Wan, W. H., Orbuch, T. L., \& Antonucci, T. C. (2017). The development of marital tension: Implications for divorce among married couples. Developmental psychology, 53(10), 1995-2006. https://doi.org/10.1037/dev0000379.

Brake, A. (2018). Visi-visi Anak Domba Komentari Wahyu. Makassar: STT Jaffray.

Dlaifurrahman, M. (2018). Cerai Paksa Akibat Campur Tangan Pihak Ketiga Perspektif

Teori Konflik. Jurnal Hadratul Madaniyah, 5(2), 31-46.

https://doi.org/10.33084/jhm.v5i2.885.

Gallagher S.J, Charles A. (1994). PASANGAN Yang SALING MENCINTAI. Jakarta: Penerbit OBOR.

Hesselgrave, David J. (2019). Communicating Christ Cross-Culturally (Mengkomunikasikan Kristus secara Lintas Budaya, Cet.Ke-3). Malang: Literatur SAAT. 
Pangaribuan, Anna Christina Vera Pangaribuan. (2015). Konseling Pastoral untuk PRANIKAH DAN KELUARGA. Pematangsiantar: Penerbit Lembaga Studi Agama dan Pembangunan ( L-SAPA).

Prihatsanti, Unika, Suryanto, \& Wiwin Hendriani. (2018). Menggunakan Studi Kasus sebagai Metode Ilmiah dalam Psikologi. Buletin Psikologi, 26(2), 126-136. DOI: 10.22146/buletinpsikologi.38895.

Ronda, Daniel. (Januari 2015). Leadership Wisdom: Antologi Hikmat Kepemimpinan. Jawa Barat: Kalam Hidup.

Scazzero, Peter. (Juli 2016). The Emotionally Healthy Leader ( Pemimpin yang sehat secara Emosi): Bagaimana Transformasi Kehidupan Batin Anda Dapat Mengubah Gereja, Pekerjaan, dan Dunia Anda secara Mendalam. Surabaya: Literatur Perkantas Jatim.

Subeno, Sutjipto. (2008). Indahnya Pernikahan Kristen. Surabaya: Penerbit Momentum.

Verkuyl, J. (1993). Etika Kristen Seksuil. Jakarta: BPK Gunung Mulia.

Yin, R. K. (2002). Case study research: Designand methods (2rd ed.). Thousand Oaks, CA: Sage. 